\title{
Seismologists claim quake data being 'mis-read' as bomb test
}

[WASHINGTON] Publicly accessible data clearly show that a seismic event in northern Russia, which has been interpreted as a possible secret nuclear weapons test, was in fact a small earthquake, according to prominent US seismologists. But they are angry that their assessment is apparently being ignored by the White House.

The event took place on 16 August more than a hundred miles from the Russian test site at Novaya Zemlya. The Clinton administration has refused to say whether it believes the event was an earthquake or a nuclear test.

"We're still reviewing the technical data that continue to come in on that incident," Bob Bell, a senior official of the National Security Council, said last week. "The data are not conclusive; they lend themselves to alternative explanations."

Jeff Smith, a spokesman for the Office of Science and Technology Policy (OSTP), which coordinates science policy at the White House, said that OSTP was part of an "interagency review" of the data. He declined to estimate when the review would be completed.

But seismologists say that data from open seismic stations in Norway, Finland and Russia already indicate clearly that the event was an earthquake, not an explosion. Not only did it take place about $130 \mathrm{~km}$ off the coast of Novaya Zemlya, but it also has a seismic signature that marks it as an earthquake rather than an explosion.

"I don't know of any seismologist who doesn't think that this was an earthquake," says Greg van der Vink, of the Incorporated Research Institutions for Seismology, a col-

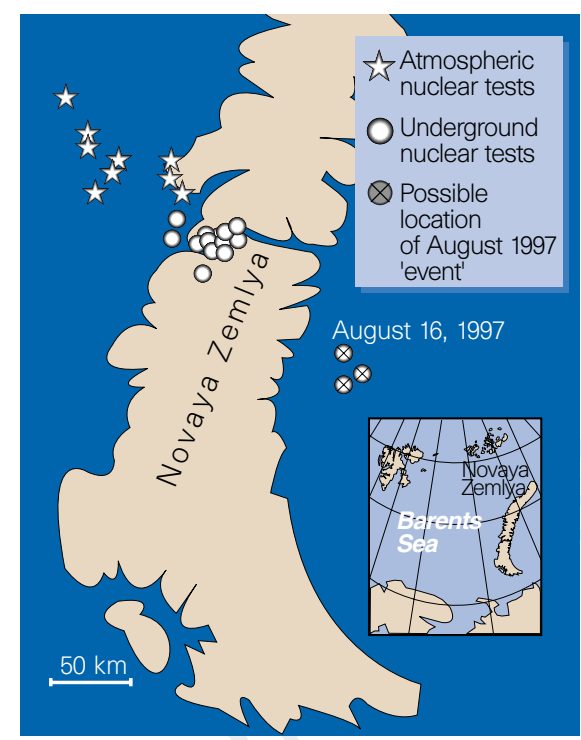

Mapping the event: location and type of wave, measured in Norway, Finland and Russia, clearly point to an earthquake, say seismologists.

laboration of 90 universities which is supported by the National Science Foundation to operate seismology research facilities.

When seismologists study such events, they measure ' $\mathrm{S}$ ' (or shear) waves as well as ' $\mathrm{P}$ ' (or compressional) waves in the Earth. Underground nuclear explosions produce a signature dominated by $\mathrm{P}$ waves, whereas earthquakes have a significant s wave component.

According to Jeffrey Park, an associate professor of geology at Yale University, the 16 August event was characterized by shear waves. "If you were looking for a potential

\section{Russian researchers brace for more cuts}

[MOscow] A reduction in science spending of about 12 per cent is being proposed in the Russian government's draft budget for 1998 , which was submitted last month to the State Duma, the lower chamber of parliament. Duma members have expressed concern about the proposed cuts.

A parallel submission to the Duma threatens to make conditions for science even more difficult by abolishing many existing laws, such as that requiring at least 4 per cent of all budget expenditures to be spent on science and at least 3 per cent on education.

"The draft budget for 1998 allocates approximately 12 per cent less for the year compared with 1997," complains Ivan Melnikov, the chairman of the Duma's committee on education and science. Under the proposals, financing of the Russian
Academy of Sciences would be reduced by 19 per cent and that of its Siberian branch by boosting research in universities would receive only half of its 1997 allocation.

News of the proposed cuts for 1998 follows a reduced budget for 1997. Melnikov says that in May the cabinet drafted a law holding back promised state expenditure in 1997 , stating that education and science were to lose more than 4,000 billion roubles (US\$700 million). These cuts were rejected by the Duma, but the government nevertheless went ahead with them.

The 1997 cuts meant that general expenditures for the first half of the year were only 70 per cent of those promised, with science receiving only 58 per cent of its planned budget, says Melnikov. Carl Levitin 25 per cent, while the programme for nuclear explosion, this just wouldn't ring any bells," he says. Several other leading Earth scientists support Park's assessment.

But press reports suggested that the event was a nuclear explosion after an unnamed Department of Defense official told the Washington Times, a conservative newspaper, that it had "explosive characteristics".

The official told the newspaper that the event undermined the Comprehensive Test Ban Treaty (CTBT), because it showed either that the Russians were cheating or that the United States was technically incapable of figuring out whether they were. Supporters of the treaty hotly dispute both assertions.

President Bill Clinton announced last week that he will now take the CTBT to the Senate, where it needs to win 67 votes out of 100 for verification. Fifty-seven of the senators are Republicans, and the Republican party is officially opposed to the treaty. Observers believe, however, that Clinton has a realistic chance of winning enough support for verification.

Senators who oppose the treaty, including Jesse Helms (Republican, North Carolina), chair of the Foreign Relations Committee, and Jon Kyl (Republican, Arizona), were quick to cite the 16 August event as justification for their opposition. Supporters of the treaty are therefore urging the administration to declare that the event was not a nuclear test.

"The administration has handled the whole episode extremely badly," says Chris Paine, an analyst with the Natural Resources Defense Council, an antinuclear lobby group. "They've known for weeks" that the incident was an earthquake, he says. "But they haven't said anything".

Paine also alleges that seismologists have been slow to speak out because many depend on the Department of Defense for funding.

A group of seismologists led by Lynn Sykes of the Lamont-Doherty Earth Observatory at Columbia University, New York, abandoned plans to hold a press conference to show their evidence that the 16 August event was an earthquake. Sykes was unavailable for comment on this decision.

Jeremy Stone of the Federation of American Scientists, a group of scientists opposed to nuclear proliferation, says that the reporting of such events has followed a familiar pattern since the height of the Cold War.

"Semi-digested intelligence information is leaked from the intelligence community, whenever it seems to suggest that an alarm bell should be rung," he says. "This leads to a permanent skewing of our view on whether the other side is cheating."

ColinMacilwain 